\title{
Metsätalouden asema kirjanpitotilojen rahaliikkeessä ja investointien rahoituksessa vuosina $1966-1975$
}

\author{
Kalevi Hemilä \\ Helsingin yliopiston maanviljelystalouden laitos, 00710 Helsinki 71
}
The role of farm forestry in the finances of farms and in the financing of investments on Finnish bookkeeping farms in 1966-1975

Kalevi Hemilä

Department of Agricultural Economics, University of Helsinki, 00710 Helsinki 71

\begin{abstract}
The purpose of this study was to explain what part the forest income has in the finances of farms and in the financing of investments and whether there in this respect can be seen any differences depending on the size and situation of the farms in our country. The material for the study comprised all the bookkeeping farms included in the agricultural profitability surveys. The period of the study covered ten fiscal years, 1966-1975.

Farm forestry occupies a prominent position in Central Finland. There the forest income made on the average even more than 20 per cent of the total cash receipts per farm. In South Ostrobothnia the forest income is much smaller than elsewhere in Finland.

The real value of the amount of money per farm used for investments has nearly been doubled. The percentage of the implements of the investment cash expenses per farm has nearly been trebled during the period of the study. The percentage of the investments in buildings has correspondingly decreased almost 50 per cent since 1966.

The average cash balance from forestry has covered around 55 per cent of the investment cash expenses per farm. According to the mean values of all the bookkeeping farms the forest income influenced especially the investments of the following year.

In 1974 there were 29 per cent of the farms of the whole material whose cash balance from forestry was $\leq 0$ and 13 per cent which had no investment cash expenses at all. In 1975 the corresponding percentages were 37 per cent and 9 per cent.
\end{abstract}

\section{Johdanto}

Maatilametsät tukevat maatilojen taloutta monin tavoin. Metsälö tyydyttää tilan oman puun tarpeen, antaa puunmyyntituloina merkittävän lisän yrityksen rahatuloihin ja luo viljelmän työ- ja vetovoimalle työllisyyttä ja ansioita varsinkin talvikautena.

Vaikka metsätalouden asema maatalouden kilpailijana, erillisenä tuotannonalana, yleensä hyväksytäänkin, pidetään metsää kuitenkin usein eräänlaisena pääomareservinä ja maatalouden rahoittajana. Kieltämättä käytännössä tilanne voi usein olla tällainen. Metsätalous toimii monissa yrityksissä eräänlaisena likviditeettipuskurina (Brandes ja Woermann 1971). Mellerowicz 
(1959) pitää metsää omaisuusosana, joka voidaan muuttaa käteiseksi maksettaessa erääntyviä maksuvelvoitteita. JARCHOwin (1966) mielestä ylijäämää tuottava metsätalous parantaa maatilayrityksen taloudellista perustaa.

Vaikka yksityinen viljelijä taloudellista tilannetta arvioidessaan kiinnittää päähuomion rahassa saamiinsa tuloihin ja rahassa maksamiinsa suorituksiin, on maatilatalouden rahaliikettä käsitelty suhteellisen vähän maatalouspoliittisissa selvityksissä ja maatalouden kannattavuustutkimuksessa. Tämä selittyy sillä, että rahaliike ei sellaisenaan kuvaa maataloudesta saatua tuloa sen enempää kuin maatalouden kannattavuuttakaan. Maatilatalouden rahaliikkeestä on tehty vain esitelmän tyyppisiä lyhyitä ja pintapuolisia selvityksiä (esim. Sauli 1960, Sipilä 1946).

Tämän tutkimuksen tarkoituksena on selvittää, mikä osuus metsätuloilla on maatilojen rahaliikkeessä ja investointien rahoituksessa ja onko tässä suhteessa havaittavissa eroja eri kokoisten viljelmien ja maan eri osien välillä. Kun tutkimus on rajattu rahaliikkeen puitteisiin, pyritään myös maatilojen rahaliikkeestä kokonaisuutena antamaan mahdollisimman selvä kuva.

\section{Aineisto}

Tutkimuksen aineistona ovat matalouden virallisessa kannattavuustutkimuksessa mukana olevat kirjanpitotilat. Tutkimusperiodi on kymmenen tilivuotta, 1966-1975. Kirjanpitoaineistossa on tulokset esitetty tutkimusalueittain ja tilasuuruusluokittain. Maa on jaettu neljään tutkimusalueeseen: EteläSuomi, Sisä-Suomi, Etelä-Pohjanmaa ja Pohjois-Suomi. Tilat on lisäksi ryhmitelty kuuteen suuruusluokkaan ns. muunnetun maatalousmaan hehtaareiden mukaan. Suuruusluokat on muodostettu seuraavasti:

$\begin{array}{lrl}\text { I } & \text { suuruusluokka } & -5 \text { ha (muunnettua maatalousmaata) } \\ \text { II } & 5-10 \\ \text { III } & 10-20 \\ \text { IV } & , & 20-30 \\ \text { V } & 30-50 \\ \text { VI } & 50- & ,\end{array}$

Kirjanpitotilojen lukumäärä on vaihdellut tutkimuskautena välillä 841-1298 (ANON. 1968-1978).

Rahaliikkeellä ymmärretään rahatulojen, rahamenojen ja niiden erotuksena syntyvän rahaylijäämän muodostamaa kokonaisuutta. Tähän kiertoon hyväksytään vain puhtaasti rahan muodossa tapahtuvat suoritteet. Niinpä viljelijän ja hänen perheensä oma työ, omasta metsästä saadun puutavaran arvo ja vastaavat luontoissuoritukset eivät kuulu maatilan rahaliikkeeseen. Rahatuloiksi ja -menoiksi lasketaan tilivuoden käteistulot ja -menot lisättyinä niiden tilikauden aikana laskuun myytyjen tuotteiden ja laskuun ostettujen tarvikkeiden arvolla, joista suoritukset ovat siirtyneet seuraavalle tilivuodelle. Termillä rahaylijäämä tarkoitetaan kaikkien ao. tilivuonna rahana saatujen tulojen ja rahalla maksettujen menojen erotusta. Tilisaatavat ja -velat on kuitenkin laskettu siihen tilivuoteen, jolloin ne ovat syntyneet.

Rahaylijäämää laskettaessa ei huomiota kiinnitetä tulojen eikä menojen luonteeseen, siis siihen, kuuluvatko ne tilivuoden liiketoimintaan vai ovatko 
ne omaisuutta realisoimalla saatua tai sen hankintaan käytettyä rahaa. Tietyn talouden alan, esim. metsätalouden, rahaylijäämä osoittaa siis koko sen rahasumman, jonka tämä talouden ala jättää käytettäväksi joko tilan rasitteiden ja velkojen suorittamiseen, veroihin, kulutukseen ruoka- ja yksityistalouksissa tai omaisuuden lisäämiseen muiden talousalojen piirissä taikka niiden mahdollisesti tuottamien alijäämien peittämiseen.

\section{Tulokset}

\section{Kokonaisrahaliike}

Keskimääräiset tilaa kohti lasketut bruttorahatulot ovat kasvaneet tutkimuskautena noin nelinkertaisiksi. Kun inflaation vaikutus eliminoidaan saadaan reaaliseksi kasvuksi noin $60 \%$. Pienimmillä tiloilla, joilla tuotanto on yleensä voimaperäistä karjanhoitoa, on saavutettu korkein bruttorahatulojen taso Pohjois-Suomessa. Yli 10 peltohehtaarin tiloilla on suurimmat nimellisrahatulot keskimäärin tilaa kohti saatu Sisä-Suomen alueella.

Suurin osa kirjanpitotilojen rahatuloista saadaan maataloudesta. Maatalouden rahatulojen keskimääräinen osuus kokonaisrahatuloista on kasvanut tutkimuskauden aikana 71,4\%:sta 81,9\%:iin.

Kokonaisrahaliike on jäänyt alijäämäiseksi useimpina tutkimusvuosina (kuva 1). Raha-alijäämät merkitsevät velkojen lisäystä tai säästöjen käyttöä vajausten peittämiseen. Kirjanpitotilojen keskimääräinen velkaisuusprosentti on noussut vuoden 1966 noin $13 \%$ :sta $19 \%$ :iin vuonna 1975.

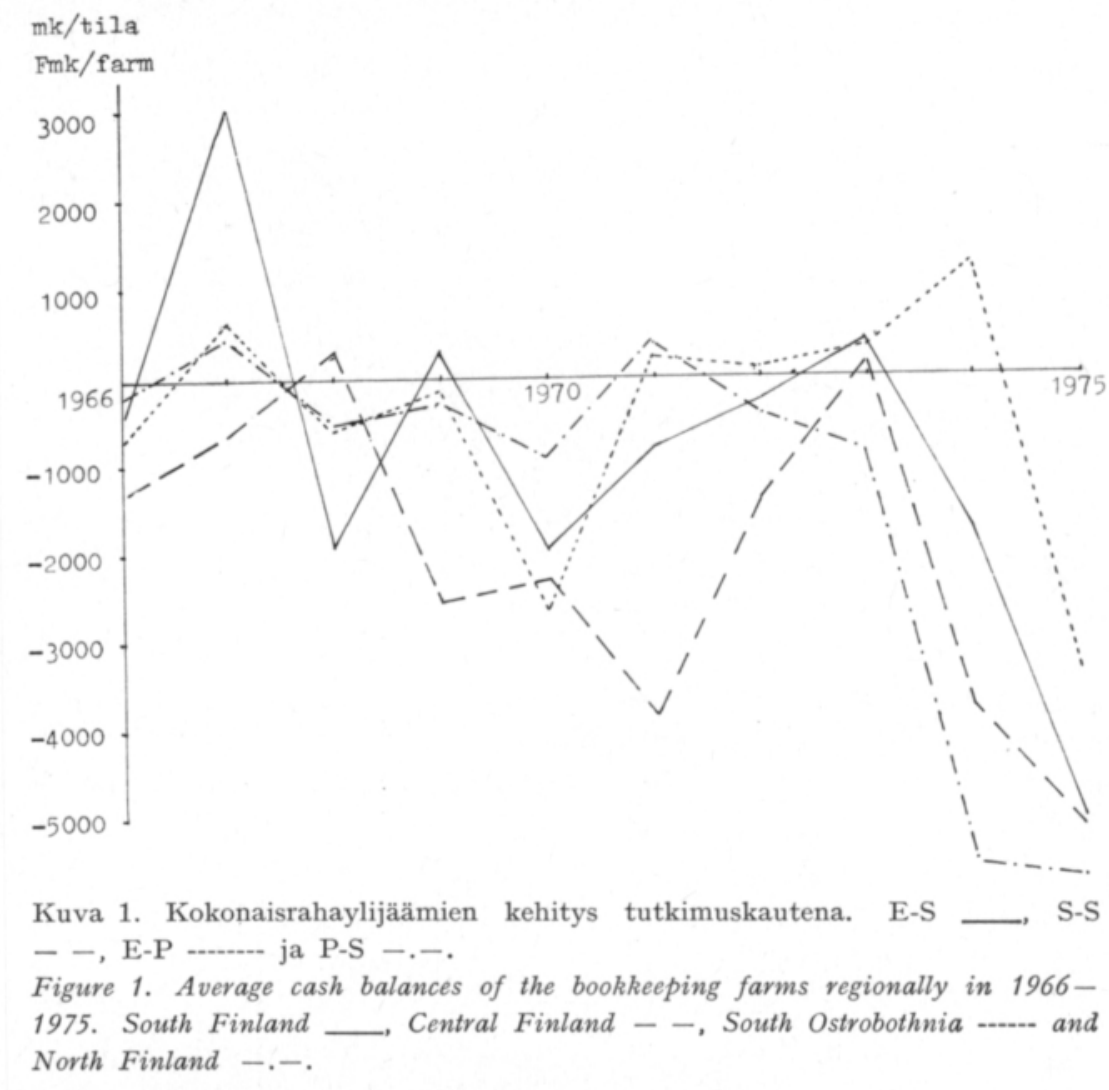




\section{Metsätulot osana kirjanpitotilojen rahaliikettä}

Metsätalouden rahatuloja ei voida kirjanpitoaineiston pohjalta yksityiskohtaisemmin eritellä. Rahatuloihin on luettu kaikki niin pysty- kuin hankintakauppanakin myydystä puutavarasta saadut rahatulot sekä kaikki muut metsätaloudesta, mm. metsämaan myynnistä, saadut rahatulot, joskin viimeksimainitut ovat harvinaisia.

Metsätaloudesta saadut rahatulot vaihtelevat vuosittain voimakkaasti, mihin vaikuttavat sekä hakkuumäärien että raakapuun hintojen muutokset. Pohjois-Suomen tutkimusalueella on puutavaran hinta ollut selvästi alempi kuin muualla maassa.

Metsätalous on keskeisessä asemassa Sisä-Suomen alueella. Siellä metsätulojen osuus kokonaisrahatuloista on ollut jopa yli $20 \%$. Etelä-Pohjanmaalla metsätalouden suhteellinen osuus on keskimäärin selvästi muuta maata alemmalla tasolla (kuva 2). Metsätaloudesta saadut markkamääräiset rahatulot kasvavat erittäin selvästi tilakoon kasvaessa.

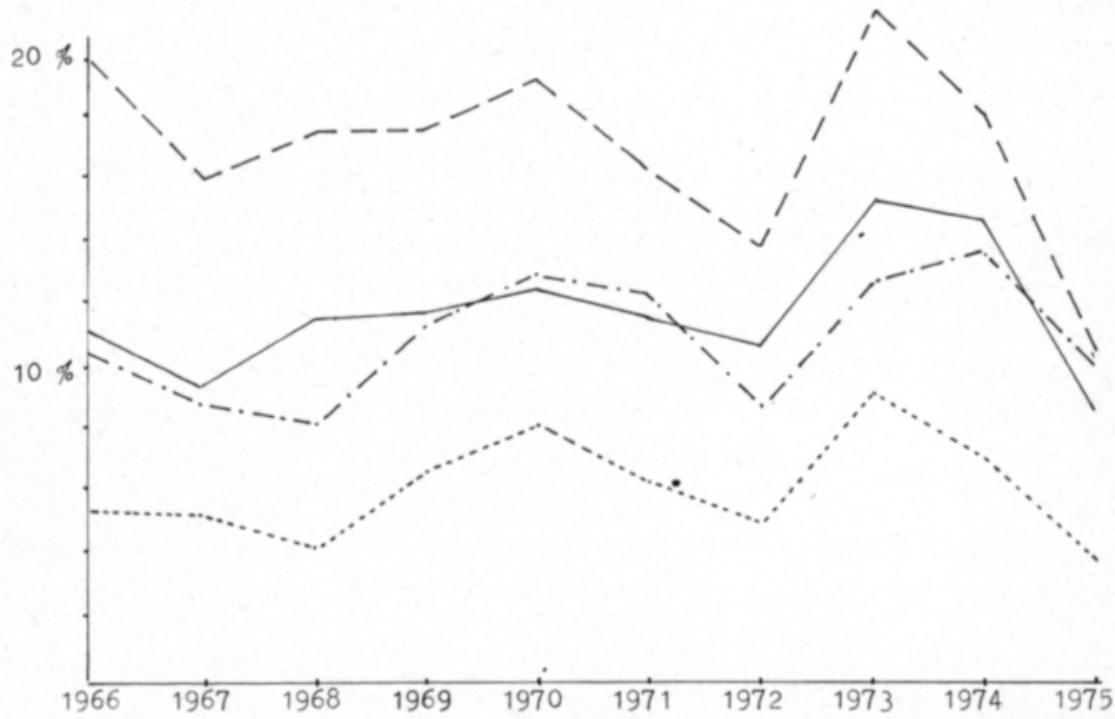

Kuva 2. Metsatalouden rahatulojen prosentuaalinen osuus kokonaisrahatuloista alueittain tutkimuskautena. E-S S-S - - E-P -...- ja P-S -.-.

Figure 2. Average cash receipts from forestry in percentage of the farmers total cash receipts regionally in 1966-1975.

\section{Investoinnit}

Kirjanpitotilojen keskimääräiset tilaa kohti lasketut investointirahamenot ovat kasvaneet tutkimusperiodin aikana peräti $368 \%$. Kiinteässä hintatasossa investointirahamenot ovat kasvaneet noin kaksinkertaisiksi. Investointirahamenojen osuus kokonaisrahatuloista on jonkin verran kasvanut. Pienimmillään osuus on ollut 15,2\% vuonna 1968 ja suurimmillaan $21,9 \%$ viimeisenä tutkimusvuonna.

Investointirahamenojen sisäisessä rakenteessa on tutkimuskauden aikana tapahtunut suuri muutos. Koneiden ja kaluston osuus tilakohtaisista investoin- 
tirahamenoista on kasvanut keskimäärin noin kolmanneksella ja uudisrakennusten osuus on vastaavasti laskenut lähes yhtä paljon. Myös vuositasolla investoinnit näihin kohteisiin näyttävät vaihtelevan vastakkaisiin suuntiin (kuva 3).

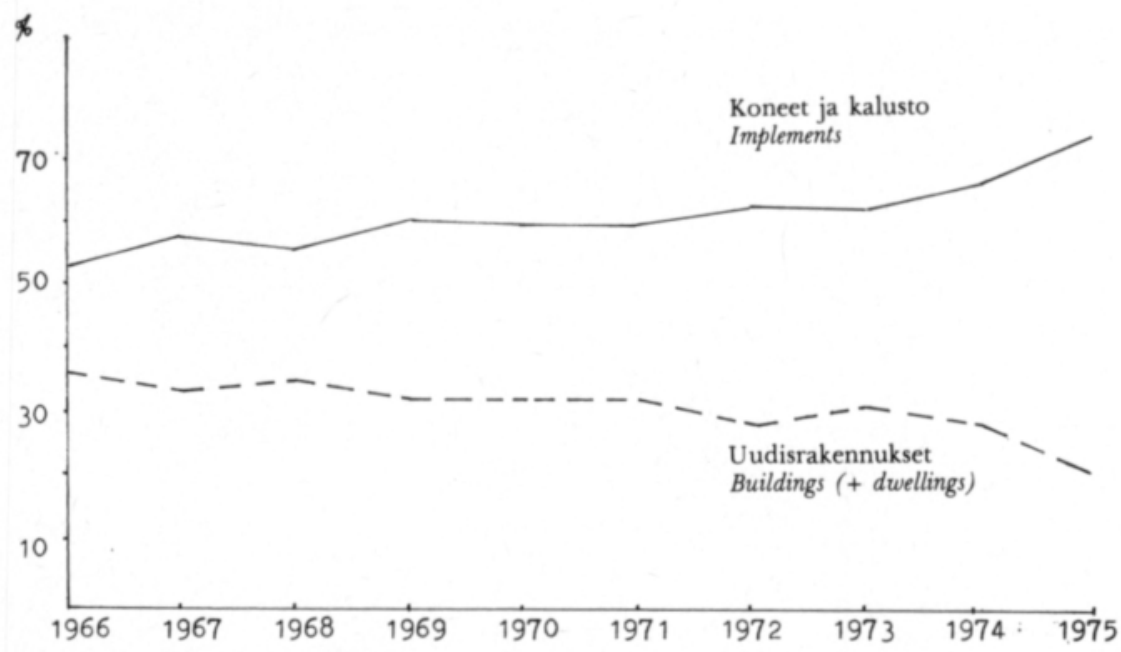

Kuva 3. Koneiden ja kaluston sekä uudisrakennusten prosenttiosuus investointirahamenoista keskimäärin kaikilla kirjanpitotiloilla.

Figure 3. Investment cash expenses in implements and buildings ( + dwellings)in percentage of the farmers total investment cash expenses in agriculture (and dwellings).

Pääomien entistä suurempi käyttö koneisiin ja kalustoon on ehkä yllättävää. Jo vuosia on maatalouden rakennemuutoksen odotettu johtavan siihen, että pääomia käytettäisiin entistä enemmän nimenomaan maatalouden rakenteen kehittämiseen. Koneiden hintojen kohoaminen on kuitenkin johtanut siihen, että suhteellisesti laskien entistä suurempi osa investointirahamenoista käytetään koneiden ja kaluston hankintaan (vrt. IнамuотіLA 1971).

\section{Metsätulojen asema rahainvestoinneissa}

Kun maatilataloudessa suoritetaan investointeja, osallistuu tarvittavan pääoman hankintaan yleensä tila kokonaisuudessaan riippumatta siitä, minkä talousalan hyväksi investointi tehdään. Metsätalouden merkitystä uudistusten rahoittamisessa tarkastellaan tässä tutkimuksessa vertaamalla metsätaloudesta saatua rahaylijäämää investointirahamenoihin. Koska eri talousalat muodostavat maatilalla varsin kiinteän kombinaation on kuvassa 4 verrattu tilakohtaisia investointirahamenoja maatalouden, sivuansiotalouden ja metsätalouden ylijäämiin keskimäärin kaikilla kirjanpitotiloilla. Maataloudesta on käytetty ns. varsinaista rahaylijäämää, jolloin ei huomioida omaisuutta myymällä saatuja tuloja.

Maatalouden varsinainen rahaylijäämä olisi keskimäärin riittänyt hyvin investointien kattamiseen, jos ylijäämällä ei olisi ollut muuta käyttöä (kuva 4). On kuitenkin ymmärrettävää, että viljelijäperhe käyttää omaan kulutukseensa suuren osan maataloudesta saatavista jatkuvista tuloista. Maatalouden varsinaisen rahaylijäämän ja investointirahamenojen kuvaajilla ei näytä olevan 


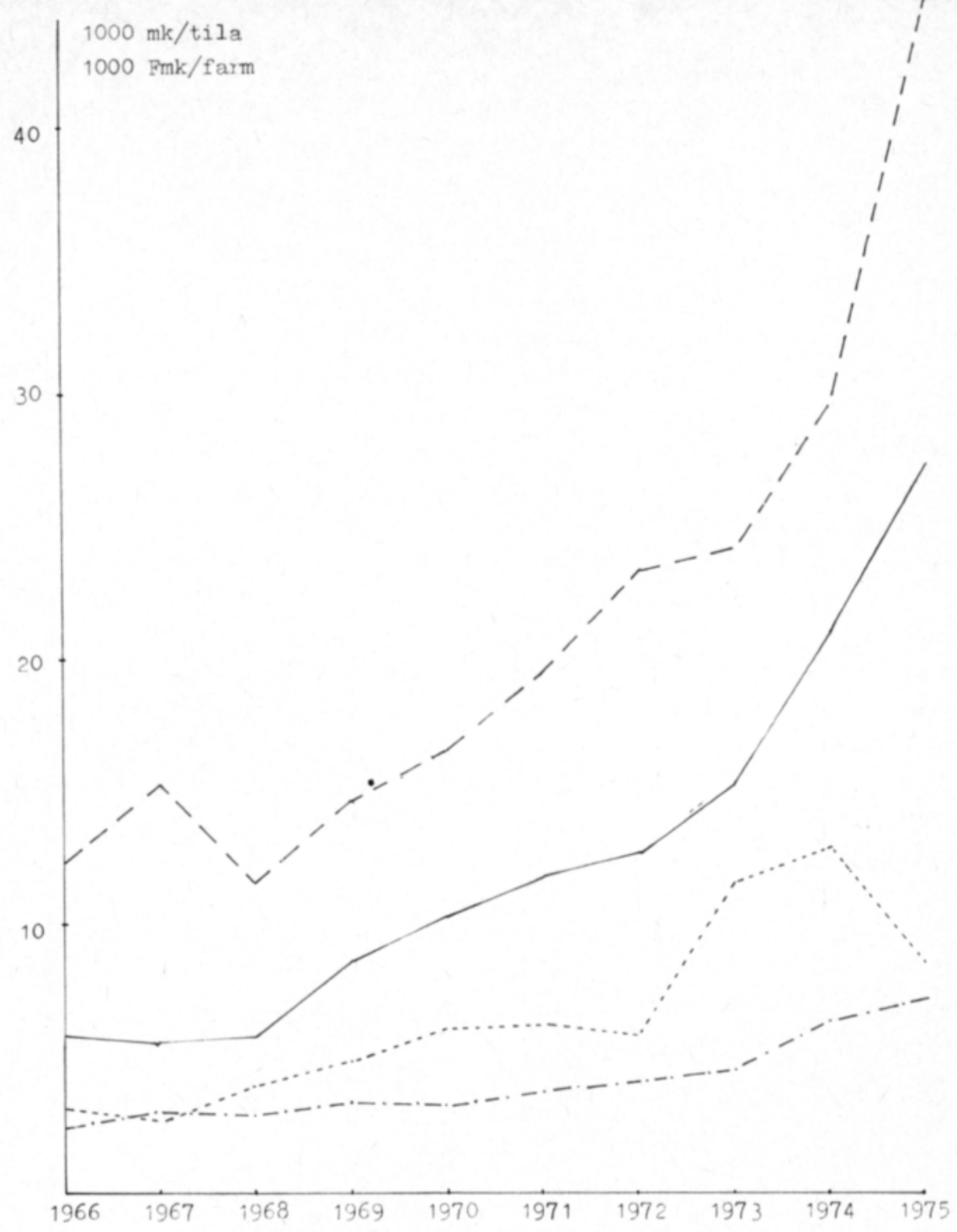

Kuva 4. Investointirahamenojen ja eri talousalojen rahaylijäämien keskimääräinen kehitys tutkimuskautena. Investointirahamenot $\longrightarrow$ metsätalouden rahaylijäämä -----, sivuansiotalouden rahaylijäämä _-_- ja maatalouden varsinainen rahaylijäämä -- .

Figure 4. Investment cash expenses __, cash balance from forestry -...-., cash balance from By-enterprises - . - and general cash balance from agriculture - on the average in 1966-1975.

kovin selviä yhteisiä kehityspiirteitä. Inflaatio on luonnollisesti kasvattanut molempia rahamääriä. Investoinnit ovat kasvaneet suhteellisesti nopeammin kuin maataloudesta saadut ylijäämät. Sivuansiotaloudesta saatu rahaylijäämä on selvästi pienentynyt suhteessa investointeihin tutkimuskauden aikana.

Metsätalouden rahaylijäämä on ollut keskimäärin noin $\mathbf{5 5} \%$ investointirahamenoista. Vuosittaiset vaihtelut ovat olleet suuria vaihteluvälin ollessa $31,6 \%$ $-76 \%$ (kuva 4 ). Kun verrataan metsäylijäämien ja investointien kuvaajia toisiinsa ei vuosittaisten arvojen välillä näytä olevan selvää riippuvuutta. 
Huiput ja aallonpohjat eivät satu samoille vuosille. Aikasarjoista voi kuitenkin nähdä varsin selvästi, että metsäylijäämien kuvaaja kulkee ikäänkuin yhden vuoden investointien edellä. Kun metsäylijäämä on aallonpohjassa vuonna 1967 ja seuraavana vuonna on havaittavissa selvä nousu, on investoinneilla aallonpohja vuonna 1968 ja nousu alkaa vasta vuonna 1969. Metsätulot näyttävät vaikuttavan seuraavan vuoden investointeihin.

Metsätalouden rahaylijäämien ja investointirahamenojen välistä yhteyttä voidaan havainnollistaa korrelaatiotarkastelun avulla. Seuraavassa esitetään yhteenvedon omaisesti tarkasteltavien rahamäärien väliset korrelaatiot koko aineiston keskiarvojen perusteella.

Nimellisarvoista lasketut korrelaatiokertoimet ovat:

$\mathrm{r}_{1}=0,78\left(\mathrm{r}_{1}{ }^{2}=0,61\right) \quad$ muuttamattomilla nimellisarvoilla ja

$r_{2}=0,93\left(r_{2}{ }^{2}=0,87\right)$, kun metsäylijäämiä on viivästetty yhdellä vuodella. Kiintein hinnoin laskettuna korrelaatiokerroin on muuttamattomilla hinnoilla $r_{3}=0,59 \quad\left(r_{3}{ }^{2}=0,35\right) \quad$ ja vastaavasti $r_{4}=0,92 \quad\left(r_{4}{ }^{2}=0,85\right)$, kun metsäylijäämiä on viivästetty.

Kuvan 5 mukaan Etelä-Suomessa kehitys on ollut suunnilleen samanlaista kuin koko maassa keskimäärin. Metsäylijäämät ovat selvästi investointeja alemmalla tasolla ja metsätalouden rahaylijäämät vaikuttavat lähinnä seuraavan vuoden investointeihin. Sisä-Suomessa metsätalouden rahaylijäämät ovat hyvin suuret investointeihin verrattuna. Vuosina 1968 ja 1973 on metsätaloudesta saatu tällä alueella enemmän ylijäämää kuin mitä on käytetty investointeihin. Etelä-Pohjanmaalla metsäylijäämillä on pystytty peittämään vain pieni osa investoinneista. Pohjois-Suomessa metsätuloilla on taas melko suuri merkitys. Siellä näyttäisi metsäylijäämien vaikutus saman vuoden investointirahamenoihin olevan suurempi kuin muualla maassa.
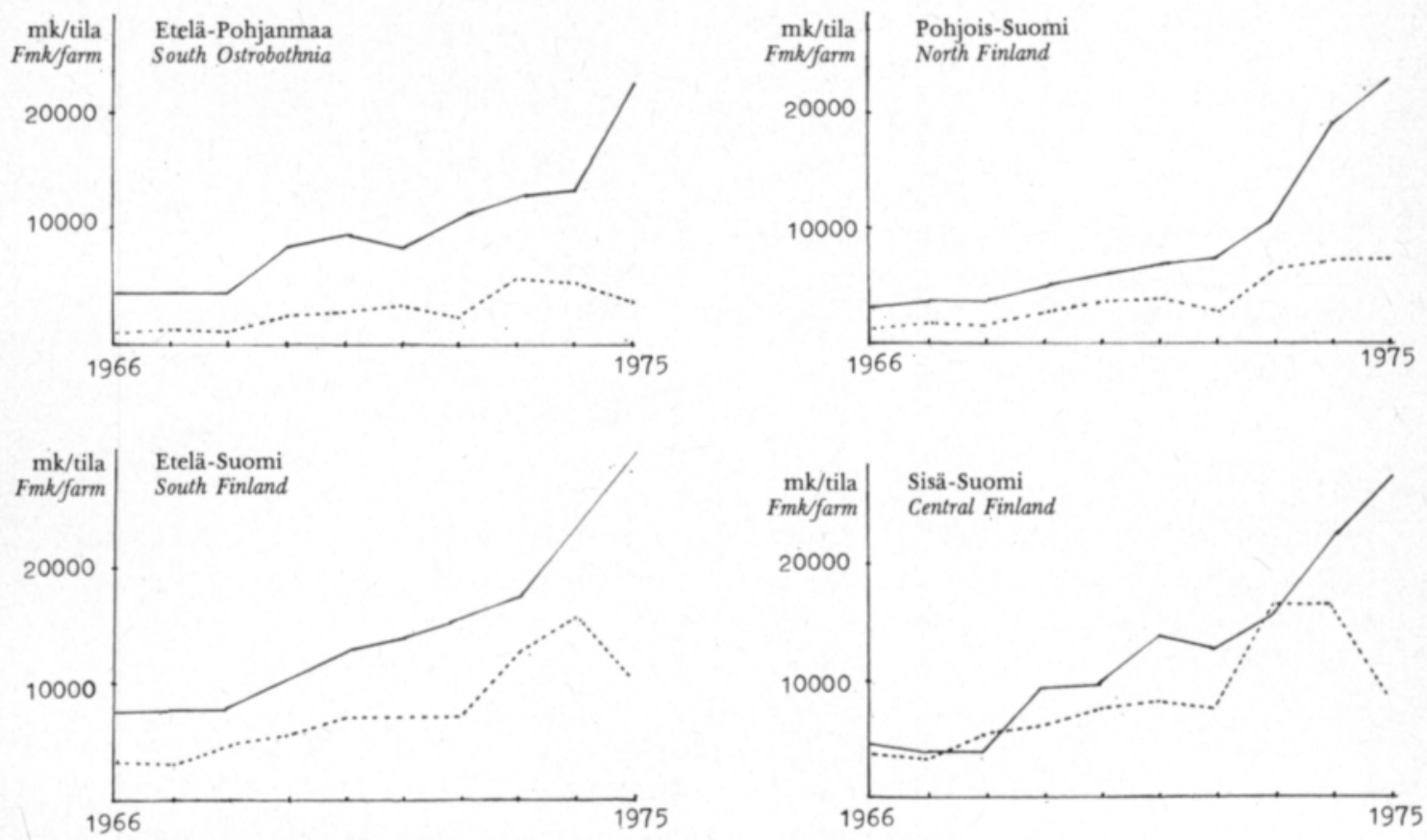

Kuva 5. Metsätalouden rahaylijäämät --..- ja investointirahamenot keskimäärin eri alueilla.

Figure 5. Cash balance from forestry and investment cash expenses on the average regionally in 1966-1975. 
Taulukko 1. Metsätalouden rahaylijäämien ja investointirahamenojen väliset suhteet tiloittain vuosina 1974 ja 1975.

Table 1. Cash balance from forestry and investment cash expenses on each farm in 1974 and 1975.

1974

Investointirahamenot,

Investment

cash expenses

1000 Fmiffarm

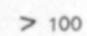

$50-100$

$20-50$

$10-20$

$5-10$

$1-5$

$0-1$

$0=$

$\sum$
Metsåtalouden rahaylijăàmăt, $1000 \mathrm{mk} /$ tila Cash balance from forestry, $1000 \mathrm{Fmk}$ farm

- 1 - in 으유유응

v $1,1,1,1,1,1,11$

$$
10-\text { in } ᄋ \text { 요 } \Sigma
$$

\begin{tabular}{llllllll}
\hline 5 & -1 & 1 & - &
\end{tabular}

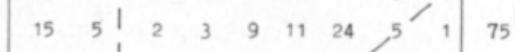

\begin{tabular}{ll|lllllllll}
40 & 7 & 5 & 15 & 16 & 29 & 41 & 6 & 2 & 161
\end{tabular}

$\begin{array}{lllllllllll}28 & 3 & 5 & 21 & 17 & 31 & 23 & 3 & 2 & 133\end{array}$

$\begin{array}{llllllllll}32 & 9 & 6 & 15 & 33 & 30 & 8 & 3 & - & 136\end{array}$

$306,10,3129: 2821-156$

$\begin{array}{lllllllll}18 & 2 & 3^{*} & 9 & 4 & 9 & 3 & 1 & -\end{array}$

$\begin{array}{lllllllllll}38 & 10 & 8 & 12 & 14 & 14 & 10 & - & - & 106\end{array}$

$\begin{array}{lllllllll}206 & 42 & 40 & 106 & 122 & 154 & 141 & 23 & 10 \Sigma \\ = & =844\end{array}$

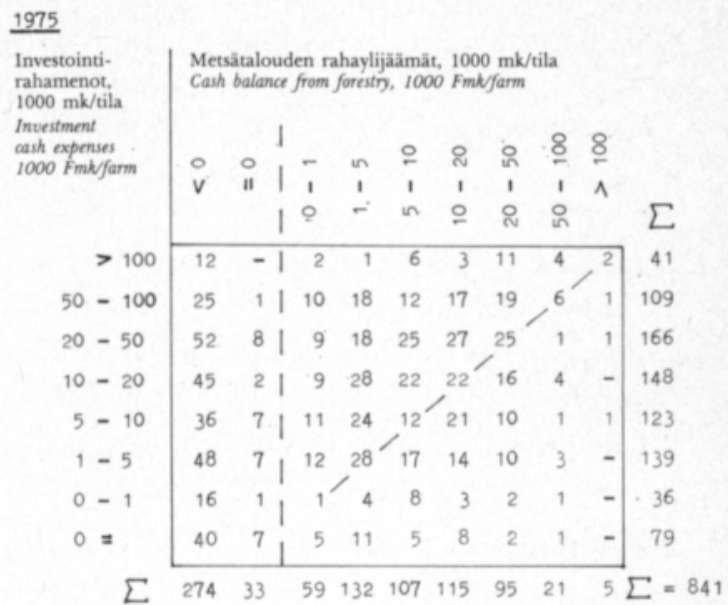

Koko aineistoa tarkastellen suurimmat poikkeamat tehdyistä päätelmistä ajoittuvat vuodelle 1973. Maataloudesta saadut tulot (vrt. kuva 4) ja velkaisuuden kasvu ovat mahdollistaneet investointitoiminnan voimakkaan lisäämisen, vaikka metsätalouden rahaylijäämät ovat olleet suhteellisen pienet.

Keskiarvolukujen ympärillä tapahtuvan tilakohtaisen vaihtelun selvittämiseksi on vuosilta 1974 ja 1975 koottu tilakohtaiset tiedot metsätalouden rahaylijäämistä ja investointirahamenoista. Koottu aineisto esitetään hajontataulukoina (taulukko 1).

Kuten kuvasta 4 nähdään, tilivuosi 1974 oli suhteellisen suurten metsäylijäämien ja invetointirahamenojen aikaa. Tästä huolimatta aineiston tiloista $29 \%$ oli sellaisia, joilla metsätalouden rahaylijäämiä ei ollut lainkaan tai ne olivat negatiivisia ja $13 \%$ :lla tiloista ei ollut investointirahamenoja lainkaan (taulukko 1). Vuonna 1975, jolloin investointirahamenot olivat keskimäärin erittäin korkealla tasolla ja metsäylijäämät olivat suorastaan romahtaneet (kuva 4), olivat vastaavat prosenttiosuudet $37 \%$ ja $9 \%$. Vuonna 1974 noin $64 \%$ :lla ja vuonna 1975 noin $59 \%$ :lla tiloista olivat molemmat rahamäärät suurempia kuin nolla.

Kun tarkastellaan taulukon 1 niitä osia, joissa metsätalouden rahaylijäämät ovat positiivisia, havaitaan muuttujien välillä varsin selvä yhteys. Aineisto keskittyy hyvin selvästi niihin ruutuihin, jotka edustavat rahaylijäämän ja investointirahamenojen samaa suuruutta, sekä niiden välittömään läheisyyteen. Tuloksista nähdään myös se, että suuret tilakohtaiset investoinnit vaativat myös suuret, lähellä samaa suuruutta olevat, metsäylijäämät.

\section{Tulosten tarkastelu}

Myös aikaisemmissa tutkimuksissa on metsätuloilla todettu olevan vaikutusta investointeihin (Piha 1957, SAUli 1960, Anon. 1957). Tässä tutkimuksessa saadut tulokset eroavat aikaisemmista selvityksistä lähinnä kahdessa 
kohdassa. Ensinnäkin nyt havaittiin metsätulojen vaikuttavan ensi sijassa seuraavan vuoden investointeihin, mitä ei aikaisemmissa tuloksissa ole ainakaan erikseen esitetty. Toiseksi metsätalouden rahaylijäämät ovat tutkimuskautena olleet keskimäärin vain $55 \%$ tilakohtaisista investointirahamenoista, kun vielä 1960-luvun alussa esitetyissä selvityksissä on todettu, että metsätaloudesta saatu rahaylijäämä on suunnilleen samaa suuruusluokkaa kuin maataloudessa suoritettujen investointien vaatimat rahamenot (esim. SAULI 1960).

Vaikka metsäylijäämillä ei kirjanpitotiloilla pystytäkään rahoittamaan kaikkia maatilan investointeja, on metsätuloilla kuitenkin edelleen varsin keskeinen asema kirjanpitotilojen rahaliikkeessä ja tulonmuodostuksessa. Puutavaran myynti antaa maanviljelijälle kerralla suuren rahasumman, jonka turvin pystytään rahoittamaan suuriakin hankkeita.

\section{Yhteenveto}

Tämän tutkimuksen tarkoituksena oli selvittää, mikä osuus metsätuloilla on maatilojen rahaliikkeessä ja investointien rahoituksessa ja onko tässä suhteessa havaittaissa eroja eri kokoisten viljelmien ja maan eri osien välillä. Tutkimusaineistona olivat maatalouden virallisessa kannattavuustutkimuksessa mukana olevat kirjanpitotilat. Tutkimusperiodi oli kymmenen tilivuotta, $1966-1975$.

Metsätalous on keskeisessä asemassa Sisä-Suomen alueella. Siellä metsätulojen osuus kokonaisrahatuloista oli keskimäärin jopa yli $20 \%$. EteläPohjanmaalla metsätulot ovat pienemmät kuin muualla maassa.

Tilakohtaiset investointirahamenot ovat kasvaneet reaalisesti noin kaksinkertaisiksi tutkimuskauden aikana. Koneiden ja kaluston osuus investointirahamenoista on kasvanut noin kolmanneksella. Uudisrakennusten osuus on vastaavasti pienentynyt lähes $50 \%$ vuoden 1966 tasosta.

Metsätaloudesta saatu rahaylijäämä on ollut keskimäärin noin $\mathbf{5 5} \%$ tilakohtaisista investointirahamenoista. Metsätulot vaikuttivat varsinkin seuraavan vuoden investointeihin.

Vuonna 1974 oli koko aineiston tiloista $29 \%$ sellaisia, joilla metsätalouden rahaylijäämä oli $\leq 0$ ja $13 \%$ :lla tiloista ei ollut investointirahamenoja lainkaan. Vuonna $19 \overline{975}$ olivat vastaavat prosenttiosuudet $37 \%$ ja $9 \%$.

ANoN. 1957. Komiteanmietintö 1957: 2. Maatalousväestön taloudellista asemaa selvittävän komitean mietintö I-II. 195 p.

ANon. 1968-1978. Tutkimuksia Suomen maatalouden kannattavuudesta. Tilivuodet 19661975. Maatal. tal. tutk. lait. julk. 12, 14, 18, 23, 27, 29, 31, 32, 34 ja 36.

Brandes, W. \& Woermann, E. 1971. Landwirtschaftliche Betriebslehre. Organisation und Führung landwirtschaftliche Betriebe. 476 p. Hamburg und Berlin. 
IндмuотіlA, R. 1971. Pääoman merkityksestä tuotannontekijänä Suomen maataloudessa vuosina 1948-1970. Osuuspankkijärjestön taloud. katsaus. 1971: 2. 6 p. Helsinki. Jarchow, H-J. 1966. Theoretische Studien zum Liquiditätsproblem. 191 p. Tübingen.

Mellerowicz, K. 1959. Allgemeine Betriebswirtschaftslehre III. 256 p. Berlin.

PıнA, A. 1957. Metsätulot ja maatilan pääoman muodostus. Referat: Waldeinkünfte und Kapitalbildung in landwirtschaftlichen Betrieben. Acta For. Fenn. 65: 1-64.

SAULI, L. 1960. Maatilatalouden rahaliike. Esitelmiä Suomen Säästöpankkiliiton maatalouspäivillä V: 1-4, 3 liitettä. Helsinki.

SıPILÃ, L. 1946. Maanviljelijän rahaliikkeestä ja sen hoidosta. Osuuskassojen Keskusliiton julk. 1, 8: 1-46.

Käsikirjoitus saapunut 10.4.1978 